\title{
A Serum Inhibitor of Insulin Action on Muscle
}

\section{Quantitative Assessement of Inhibitory Activity*}

\author{
D.A.B. Young and B. Benson** \\ Institut de Biochimie Clinique, University of Geneva, Switzerland
}

Received: January 18, 1968

Summary. 1. The intraperitoneal assay of insulin has been used to compare the effectiveness of insulin injected in serum with that of insulin injected in $5 \%$ albumin. The difference was interpreted as being due to a serum inhibitor of insulin action on muscle. - 2. To obtain a quantitative assessment of the inhibitory activity, the insulin effectiveness was estimated by the arithmetic subtraction of the effect of the serum alone from that of the insulin added to the serum. Since the effect of insulin is related to the logarithm of the dose, such a subtraction requires that the two forms of insulin-like activity are essentially different. - 3. Dose-response curves for insulin injected in albumin and in serum were parallel, despite the considerable ILA of the serum; and analysis of the phenomenon clearly shows that the effects of the serum ILA and the added insulin were arithmetically additive. - 4. The ILA of the serum was distinguishable from that of the added insulin in not being suppressed by potent anti-insulin serum in the intraperitonoal assay system used. - - 5. The consistency in the results obtained by the application of this procedure to the data of a variety of experiments provides effective support for the procedure.

Un inhibiteur sérique de l'action de l'insuline sur le muscle: II. Examen quantitatif de l'activité inhibitrice

Résumé. 1. L'essai biologique intrapéritonéal pour la mesure de l'insuline a été utilisé pour comparer l'efficacité de l'insuline injectóe avec du sérum à celle de l'insuline injectée dans de l'albumine à $5 \%$. La différence d'efficacité a été attribuée â un inhibiteur sérique de l'action de 1'insuline sur le muscle. -2 . Pour obtenir une estimation quantitative de cette activité inhibitrice, l'efficacité de l'insuline a été calculée par la soustraction de l'effet du sérum seul de celui de l'insuline ajoutée au sérum. Puisque l'effet de l'insuline est fonction du logarithme de la dose, une telle soustraction exige que les deux formes d'activité «insulinlike» (ILA) soient essentiellement différentes. - 3. Malgré la forte quantité d'ILA dans le sérum, les courbes dose-réponse de l'insuline injectée dans le sérum seul et dans l'albumine sont parallèles; l'analyse de ce phénomène démontre clairement que les effets de l'ILA sérique et de l'insuline ajoutée sont arithmétique- ment additifs. - 4. Dans le système d'essai intrapéritonéal utilisé, l'ILA du sérum peut être distinguée de l'action de l'insuline ajoutée, car elle n'est pas supprimée par un puissant sérum antiinsulinique. - 5. Le fait que cette méthode, appliquée aux données de toute une série d'expériences, donne lieu à des résultats consistants, est un élément important en sa faveur.

Ein Serum-Inhibitor der Insulinwirkung am Muskel: 2. Quantitative Bewertung der Hemmwirkung

Zusammenfassung. 1. Die Methode der intraperitonealen Insulin-Bestimmung wurde verwandt, um die Wirksamkeit von in Serum injizierten Insulin mit der von Insulin $\mathrm{zu}$ vergleichen, das in 5\% iger Albuminlösung injiziert worden war. Der Unterschied wurde als Wirkung eines Seruminhibitors der Insulinwirkung am Muskel aufgefaßt. - 2. Um quantitative Anhaltspunkte über die Hemmwirkung zu erhalten, bestimmten wir dio Wirksamkeit des Insulins, indem wir die Werte, die sich bei alleiniger Injektion von Serum ergaben, arithmetisch von denen subtrahierten, die bei Injektion von Serum mit Insulinzusatz resultierten. Da die Wirkung des Insulins vom Logarithmus der Dosis abhängt, setzt eine solche Subtraktion voraus, daß sich die beiden Formen der insulin-ähnlichen Aktivität grundsätzlich unterscheiden. 3. Die Dosis-Wirkungskurven verliefen für Insulin, das zusammen mit Serum oder mit Albumin injiziert worden war, parallel trotz erheblichen Serumgehaltes an ILA. Die Analyse der Befunde zeigt eindertig, daß sich die Wirkungen der Serum-ILA und des zugesetzten Insulins arithmetisch addierten. - 4. Im Unterschied zum zugesetzten Insulin konnte die Serum-ILA in dem von uns verwandten intraperitonealen Nachweissystem auch durch Zugabe starker Anti-Insulin-Seren nicht unterdrückt werden. - 5. Die gute Utbereinstimmung in den Ergebnissen, die wir bei der Anwendung dieses Berechnungsverfahrens auf die Daten einer ganzen Reihe verschiedener Experimente erhielten, spricht deutlich zu Gunsten des Verfahrens.

Key-words: Insulin inhibitor, serum insulin inhibitor, insulin-like activity, nonsuppressible insulin-like activity.
In the first paper of this series [10] evidence was presented for the existence in sera from males of several species (human, rat, pig, mouse and ox) of a substance that acts as an inhibitor of the action of insulin on muscle but not of insulin action on adipose tissue. Experiments using extracts of serum suggested

* Supported by the Fonds National Suisse de la Recherche Scientifique, Grant No. 3618, and a Grant-in-aid, Sandoz Pharmaceutical Co. Ltd, Basel, Switzerland.

** Supported by United States Public Health Service, Grant No. F2, AM-23, 661. Present address: Dept of Anatomy, University of Tennessee Medical Unit, Memphis, Tenn. U.S.A. that the inhibitor was a polypeptide of molecular weight 5000-10000, associated with the albumin fraction. The inhibitory activity of the sera was detected using the intraperitoneal assay for insulin [8]. Serum together with radioactive glucose, with and without insulin, was injected intraperitoneally into fasted rats, and the incorporation of radioactive glucose into diaphragm glycogen was determined. The insulin effectiveness in such experiments was compared with that of insulin injected in a solution of bovine serum albumin $(5 \mathrm{~g} / 100 \mathrm{ml})$, the latter having been established as an injection medium permitting maxi- 
mum insulin activity. Although in most instances the total effect of insulin and serum injected together was less than that of the same dose of insulin given in albumin, any quantitative assessment of the inhibitory activity must obviously take into account the contribution of the insulin-like activity (ILA) of the serum itself. One approach is to substract arithmetically the effect of the endogenous insulin of the serum from the total effect of the serum and added insulin. But because the effect of insulin is related to the logarithm of the dose, this procedure is applicable only if it can be actually demonstrated that the effects are due to essentially different forms of insulin-like activity.

Evidence is given in this paper that the effect of the ILA in serum from rats fasted overnight is in fact arithmetically additive to the effect of added crystalline insulin; and that the ILA of the serum is distinguished from that of the added insulin in not being suppressed by potent anti-insulin serum in the intraperitoneal assay system used. Lastly, the consistency in the results obtained by the application of this procedure to the data of a variety of experiments supports the validity of this argument.

\section{Methods}

Details of the intraperitoneal assay, the preparation of sera and other methodology have been given elsewhere [10]. A modification of the double-antibody precipitation methods of MoRgar and LAzARow [7] and HALES and RANDLE [5] was used for the radioimmunological measurement of insulin.

\section{Results and Discussion}

In the first paper of this series [10] dose-response curves were shown for insulin given in rat serum (from males fasted $15 \mathrm{~h}$ ) and in a $5 \%$ solution of bovine serum albumin. In those particular experiments with rat serum, the effect of the serum alone was found to be $56 \%$ of that of $1000 \mu \mathrm{U} / \mathrm{ml}$ of insulin in albumin. Both from an extrapolation of that curve and from the more complete dose-response curve for insulin injected in albumin', which is shown in Fig. 1, it can be calculated that the ILA of that serum was equivalent to $250 \mu \mathrm{U} / \mathrm{ml}$. The effect, however, of the serum with $1000 \mu \mathrm{U} / \mathrm{ml}$ of added insulin was not that of 1250 $\mu \mathrm{U} / \mathrm{mI}$, but of $2500 \mu \mathrm{U} / \mathrm{ml}$. The same phenomenon was observed with the other two doses of insulin used: serum with $250 \mu \mathrm{U} / \mathrm{ml}$ of added insulin had an effect of $650 \mu \mathrm{U} / \mathrm{ml}$ rather than $500 \mu \mathrm{U} / \mathrm{ml}$; and with 500 $\mu \mathrm{U} / \mathrm{ml}$ of added insulin, an effect of $1450 \mu \mathrm{U} / \mathrm{ml}$ rather than $750 \mu \mathrm{U} / \mathrm{ml}$. Indeed, such a disagreement between the predicted and the observed activities must follow from the observed parallelism of the dose-response

1 This curve agrees exactly with that obtained in the previous experiments (10) where only 3 doses of insulin were used. curves for insulin in serum and in albumin (Fig. 2a). If the ILA of the serum behaved in exactly the same manner as the added insulin, then the dose-response curves would converge at higher insulin concentrations; and consequently, subtraction of the effect of the serum insulin from the curve for insulin added to

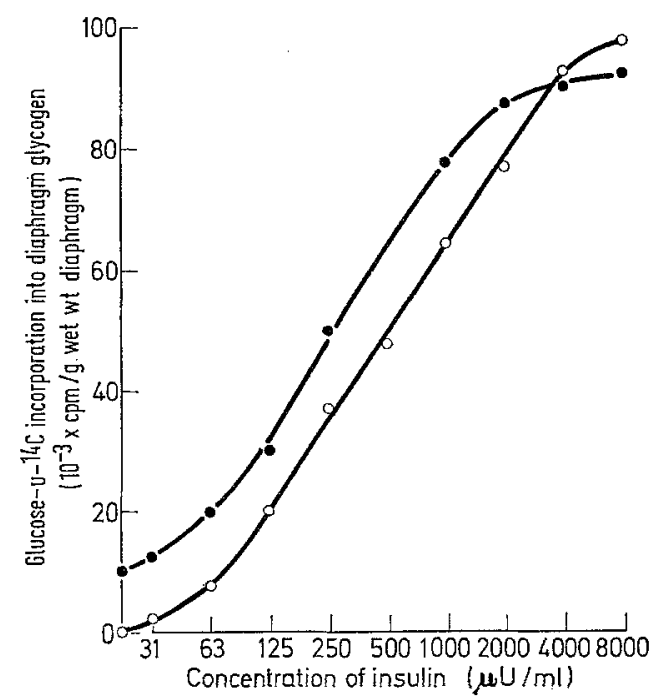

Fig. 1. Dose-response curves of insulin injected in $5 \%$ bovine serum albumin ( 0 ) and in serum from male rats fasted for 3 days $(\bullet)$. Serum pooled from 24 rats. In the bioassay 7 rats per value, except for 125, 250, 1000 and $2000 \mu \mathrm{U} / \mathrm{ml}$ where 14 or more rats were used. The incorporation of radioactive glucose into glycogon with the albumin solution without insulin was 0.3 on the scale used here $\left(10^{-3} \times \mathrm{com} / \mathrm{g}\right)$; this baseline value was not subtracted from the other values in the series

serum would give diverging lines (Fig. $2 \mathrm{~b}$ ). Thus there is a clear discrepancy between the hypothetical doseresponse relationship based on the assumption that endogenous serum ILA and exogenous insulin have identical effects, and the dose-response curve in fact observed. These results are in contrast to those of Froesch et al. [2], who found that the addition of crystalline insulin to a purified preparation (mol. wt. $5-10000$ ) of the non-suppressible ILA (NSILA) resulted in a logarithmic rather than an arithmetic addition of their effects on adipose tissue in vitro. But as those authors demonstrated, the properties of this purified preparation of NSILA were substantially different from those of the NSILA fraction of the serum (mol. wt. 70-150 000); the former being highly active in vivo, whereas the latter, although active in vitro, was not active in vivo. Their later work [6] makes it clear that less than $10 \%$ of the serum NSTLA is accounted for by this small molecular species, which is soluble in acid ethanol; the overwhelming proportion $(90 \%)$ of the serum NSILA is in fact precipitated by the acid ethanol extraction, and there appears to be no chemical relationship between the two forms. In 
fact those authors in previous work [1] obtained with serum (diluted $1: 5$ ) the same phenomenon seen here in the experiments using the intraperitoneal method; i.e. the effect of crystalline insulin added to serum was much greater than anticipated on the basis of a lo-

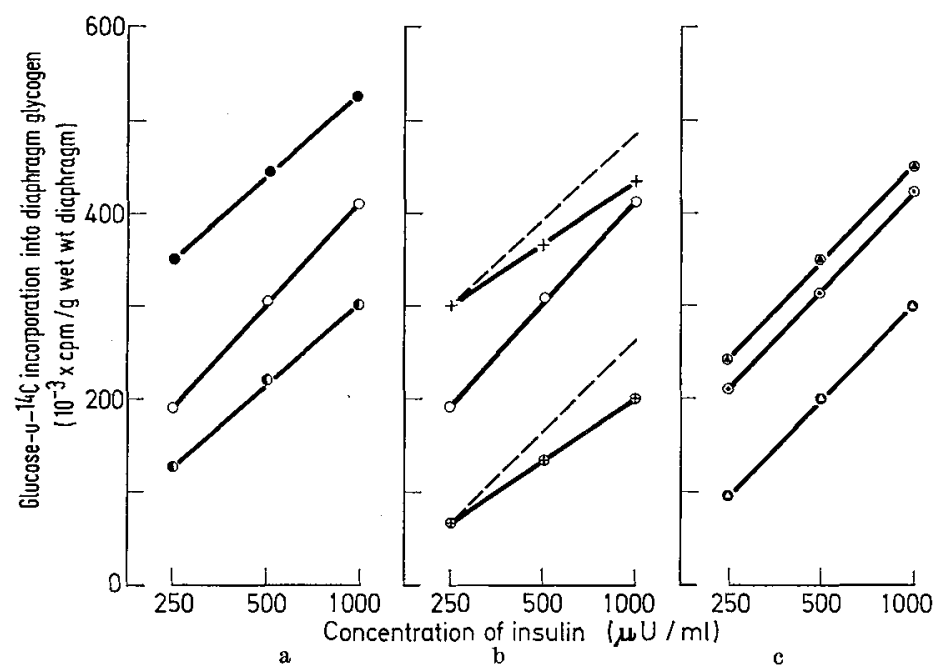

Fig. 2. Dose-response curves for insulin injected in $5 \%$ bovine serum albumin and in serum from male rats fasted overnight. (a) $\circ$ insulin in albumin; - insulin in serum; 0 insulin in serum minus the effect of the serum alone; (b) $\circ$ insulin in albumin; + hypothetical curve for insulin in serum (the insulin-like activity of the serum is assumed to be identical in behaviour with the added insulin); the same curve minus effect of serum; the dotted lines are the curves for serum in $2 a$ adjusted to the same initial value as the hypothetical curves in this figure; (c) o insulin in albumin; insulin in serum (insulin-like effect of this serum is much less than that in 2 a); - same curve minus effect of serum. In the bioassay 12 rats used per value
The insulin-like effect of dialyzed serum from rats fasted 3 days was quite appreciable, amounting to $19 \%$ of the effect of $1000 \mu \mathrm{U} / \mathrm{ml}$ of insulin in albumin (Table 3). Such an effect corresponds to $85 \mu \mathrm{U} / \mathrm{ml}$ of insulin (Fig. 1); whereas even before dialysis the mean concentration of insulin measured immunologically was only $28 \pm 1.5 \mu \mathrm{U} / \mathrm{ml}$ for four different pooled samples of such sera, decreasing to $21 \mu \mathrm{U} / \mathrm{ml}$ after dialysis. Such a discrepancy suggests that the major part of the endogenous ILA of the serum is not immunologically active. If this is true, then, as with other bioassay procedures, the addition of a potent anti-insulin serum should suppress the action of the exogenous insulin injected with the rat serum, but be largely without effect on the activity of the endogenous ILA.

Anti-insulin serum from guinea-pigs was used, $1 \mathrm{ml}$ of which could neutralize 2.6 units of insulin; and $0.1 \mathrm{ml}$ of the anti-serum was added to $8 \mathrm{ml}$ of the serum or the albumin used in the assay. Experiments were carried out using the serum from both rats fasted. overnight and rats fasted 3 days. The results are given in Table 1. The anti-serum, which completely nullified the effect of $1000 \mu \mathrm{U} / \mathrm{ml}$ of insulin added to the albumin, was without effect on the ILA of the serum from rats fasted 3 days, and reduced to only a small extent the ILA of the serum from rats fasted overnight. The failure of the anti-insulin serum to reduce the ILA of the serum from rats fasted 3 days follows from the dose-response curve of insulin injected in that serum (Fig. 1): garithmically additive effect, and accordingly the insulin recovered was considerably greater than the insulin added (e.g. 200 and $500 \mu \mathrm{U} / \mathrm{ml}$ added gave recoveries of 265 and $807 \mu \mathrm{U} / \mathrm{ml}$ respectively).

In the particular experiment used as the example so far, the effect of the ILA of the serum was much higher $(56 \%$ of the effect of $1000 \mu \mathrm{U} / \mathrm{ml}$ of insulin in albumin) than that found in most experiments. However, dose-response curves for insulin injected in serum that had a lower level of ILA, and in albumin showed the same parallelism seen in Fig. $2 \mathrm{a}$, as illustrated by the example given in Fig. $2 \mathrm{c}$.

The dose-response curves of insulin injected in sera from rats fasted 3 days (Fig. 1), from hypophysectomized rats, and from female rats in oestrus also gave lines that were parallel with the dose-response curve for insulin injected in albumin. After subtraction of the effect of the serum ILA, the curves were coincident with the dose-response curve of insulin injected in albumin. Thus the same phenomenon is found with these sera as with the serum from normal male rats fasted overnight, but in these instances the subtraction procedure indicates the absence of insulin inhibition.
Table 1. Effect of addition of anti-insulin serum a ${ }^{\mathrm{a}}$ on the insulin-like activity of serum from rats fasted overnight and rats fasted 3 days. Data expressed as percentage of the effect of insulin $(1000 \mu \mathrm{U} / \mathrm{ml})$ added to $5 \%$ bovine serum albumin. In the bioassay 7 rats used per value

\begin{tabular}{lc}
\hline & Insulin effect \\
\hline Albumin : & \\
albumin + insulin $(1000 \mu \mathrm{U} / \mathrm{ml})$ & $100.0 \%$ \\
albumin & 0.3 \\
albumin + antiserum & 0.4 \\
albumin + insulin $(1000 \mu \mathrm{U} / \mathrm{ml})$ & 0.3 \\
+ antiserum & \\
& \\
Serum from rats fasted overnight: & 19.0 \\
serum & 14.0 \\
serum + antiserum & \\
& \\
Serum from rats fasted 3 days: & 18.0 \\
serum 1 & 17.0 \\
serum 1 + antiserum & 16.0 \\
serum 2 & 17.0 \\
serum 2 + antiserum &
\end{tabular}

a guinea-pig anti-insulin serum, $1 \mathrm{ml}$ of which neutralized $2.6 \mathrm{U}$ of insulin; $0.1 \mathrm{ml}$ was added to $8 \mathrm{ml}$ of serum or albumin used in the assay. 
$20 \mu \mathrm{U} / \mathrm{ml}$ of insulin is almost without effect, and consequently the removal of that amount would not be detectable. However, if the effects of the two forms of ILA were not arithmetically additive, then a decrease of $20 \mu \mathrm{U} / \mathrm{ml}$ from 85 to $65 \mu \mathrm{U} / \mathrm{ml}$ should be detectable, as can be seen in the dose-response curve for insulin injected in albumin (Fig. 1). With the serum from rats fasted overnight, which contained $31 \mu \mathrm{U} / \mathrm{ml}$ of immunologically reactive insulin after dialysis (45 $\mu \mathrm{U} / \mathrm{ml}$ before), a measurable effect of the antiserum on the ILA might be expected, and was in fact obtained.

Several authors [1,9] have described a form of circulating ILA that is not affected by anti-insulin serum. This observation of an 'atypical' or 'non-suppressible' insulin was originally made using the epididymal adipose tissue assay; however, later work has shown that the non-suppressible ILA of the serum is active on the diaphragm in vivo, using the intraperitoneal assay [3]. A point of some interest in regard to the properties of the non-suppressible ILA in serum from rats fasted 3 days is shown in Fig. 1. There it can be seen that although the dose-response curve of insulin injected in the serum is parallel to that of insulin injected in albumin, indicating that the two activities are arithmetically additive and that there is no inhibitory activity in the serum, the two curves become coincident at concentrations of insulin greater than $2000 \mu \mathrm{U} / \mathrm{ml}$. One possible explanation for this effect is that both forms of ILA act at the same site, but that the non-suppressible insulin has a radically different affinity for this site.

Table 2. Insulin-like effect of serum, and of insulin 1000 $\mu U(m l)$ added to the serum, expressed as a percentage of the effect of insulin $(1000 \mu \mathrm{U} / \mathrm{ml})$ added to $5 \%$ bovine serum albumin

\begin{tabular}{llll}
\hline Species & Serum & $\begin{array}{l}\text { Serum } \\
\text { insulin }\end{array}$ & $\begin{array}{l}\text { Effect of } \\
\text { added insulin }\end{array}$ \\
\hline Rute $_{\text {Man }}$ c & $29 \pm 0.3(5)$ & $88 \pm 2.0(5)$ & $59 \pm 2.3(5)$ \\
Mouse $^{\mathrm{d}}$ & 16 & 76 & 60 \\
Pig $^{\mathrm{c}}$ & 12 & 67 & 55 \\
Ox $^{\mathrm{e}}$ & 4 & 51 & 47 \\
Sheep $^{\mathrm{e}}$ & 26 & 66 & 47 \\
Guinea-pigc $^{\mathrm{c}}$ & 8 & 113 & $87^{\mathrm{f}}$ \\
\hline
\end{tabular}

a serum for each experiment pooled from: 7 rats; 8 men; 75 mice; 2 pigs; 2 oxen; 2 sheep; 5 guinea-pigs. In the bioassay 7 rats used per value except for human serum where 12 were used. One assay for each serum except for rat serum, where the mean \pm S.E.M. is given for 5 assays.

$\mathrm{b}$ obtained by subtraction of insulin-like effect of serum from the effect of the serum + insulin; expressed as percentage of effect of insulin in albumin.

c fasted overnight.

a fed.

e ruminant.

f not significantly different from $100 \%(P>0.1)$.

During the course of this investigation there has been a substantial decrease in the ILA of the various preparations of rat serum, which is evident from the comparison of the data in Fig. 2 a with those in Table 3. This change is probably due to changes in the manner of preparing and treating the serum, and the constancy of the data in Table 3 may reflect the standardization of the procedure. Several authors have reported that the level of serum ILA, and more specifically the nonsuppressible form, is very dependent on the treatment [4].

Table 3. Insulin-like effect of various rat sera and and insulin $(1000 \mu U / \mathrm{ml})$ added to those sera, expressed as a percentage of the effect of the same dose of insilin added to $5 \%$ bovine serum albumin

\begin{tabular}{llcc}
\hline $\begin{array}{l}\text { Condition of } \\
\text { rats }\end{array}$ & Serum & $\begin{array}{l}\text { Serum } \\
\text { insulin }\end{array}$ & $\begin{array}{c}\text { Effect of } \\
\text { added } \\
\text { insulin }\end{array}$ \\
\hline Normal males & 28 & 93 & 66 \\
fasted overnight & 30 & 88 & 58 \\
& 29 & 81 & 52 \\
& 29 & 89 & 60 \\
fasted 3 days & 29 & 87 & 58 \\
& 19 & 110 & 90 \\
& 17 & 118 & 100 \\
& 29 & 124 & 96 \\
& 17 & 121 & 103 \\
fasted 3 days and & 13 & 107 & 90 \\
refed 1 1 $1 / 2$ & 15 & 111 & 96 \\
& 13 & 76 & 63
\end{tabular}

Hypophysectomized

males

fasted overnight

operated 10 days

8
10
16
20

$\begin{array}{lr}101 & 94 \\ 111 & 100 \\ \mathbf{1 1 5} & 101 \\ 120 & 100\end{array}$

operated 6 weeks

3

103

100

Normal females

fasted overnight

$\begin{array}{llll}\text { oestrus } & 35 & 130 & 95 \\ \text { dioestrus } & 40 & 100 & 60\end{array}$

a serum for each experiment pooled from 7 rats; in the bioassay 7 rats used per value.

b obtained by subtraction of insulin-like effect of serum from the effect of the serum + insulin; expressed as percentage of effect of insulin in albumin.

The consistency of the results obtained by the application of this procedure of subtracting the endogenous ILA of the serum, although not constituting in itself evidence for the validity of the method, certainly provides effective support. Thus we have found that the ILA of the serum itself appears to vary very considerably from species to species. As is shown in Table 2, the insulin-like effect of the serum alone, expressed as a percentage of the effect of $1000 \mu \mathrm{U} / \mathrm{ml}$ of insulin injected in albumin, varies from $4 \%$ with serum from pigs fasted overnight to $30 \%$ or more with serum from rats fasted overnight. In addition, it can also be 
seen that the total insulin-like effect of insulin injected in serum from either sheep or guinea-pigs is greater than that of the insulin injected in albumin, and that subtraction of the effect of the serum alone still results in the effectiveness of the added insulin being the same as, or greater than that of insulin injected in albumin. On this basis, one could say that there was no inhibitory activity in the sera from these two species. When applied to the other sera, the subtraction procedure yields a fairly consistent figure of about $50 \%$ for the ratio of the insulin effectiveness in serum to that in albumin.

The degree of insulin inhibitory activity in rat serum was found to depend upon the sex, the presence of the pituitary and the nutritional state of the animal. The details of this work will be given in full in later papers of this series, but the essential data are given in Table 3. The data for each experiment are given separately, since this permits a better appreciation of the reproducibility of the experiments. It can be seen that although the inhibitory activity was absent in certain conditions (at oestrus, after fasting for 3 days, after hypophysectomy), the ILA of the serum was either unchanged or only moderately reduced. Probably the most significant data in this respect were those obtained by feeding rats fasted for 3 days: the inhibitory activity of the serum, which had disappeared with fasting, reappeared about $1 \frac{1}{2}$ after feeding, but apparently before any insulin was released; that is the ILA of the serum remained the same but the effect of added insulin was significantly decreased.

Acknowledgement. The authors gratefully acknowledge the technical assistance of Miss D. Duviluard.

\section{References}

1. Froesch, E.R., H. BÜrgt, E.B. Ramsier, P. Batix, and A. LABHART: Antibody suppressible and nonsuppressible insulin-like activities in human serum. and their physiological significance. An insulin assay with adipose tissue of increased precision and specificity. J. clin. Invest. 42, 1816-1834 (1963).

2. - W.A. MüLLER, H. BürGT, M. WALDVOGEL, and A. LABHART : Non-suppressible insulin-like activity of human serum. II. Biological properties of plasma extracts with non-suppressible insulin-like activity. Biochim. biophys. acta 121, 360-374 (1966).

3. - - R.E. Humber, A. JACOB, and A. Labhart: Non-suppressible insulin-like activity of human serum: purification, physicochemical and biological properties and its relation to total serum ILA. Recent Progr. Hormone Res. 23, 565-605 (1967).

4. Gummann, J.: Assay of insulin-like activity by the isolated fat cell method. III. Studies on the non-suppressible insulin-like activity of serum. Diabetologia 4, 95-104 (1968).

5. HALES, C.N., and P.J. RANDLE: Immunoassay of insulin with insulin-antibody precipitate. Biochem. J. 88, 137-146 (1963).

6. JACOB, A., R.E. Humber, U. BuxtorF, and E.R. Frowscr: Separation and properties of two different molecules with non-suppressible insulin-like activity from human plasma. Abstract, European. Assoc. for Study of Diabetes. 4th Annual Meeting, Louvain. 1968 .

7. Morgan, C.R., and A. Lazarow: Immunoassay of insulin: two antibody system. Plasma insulin levels of normal, subdiabetic and diabetic rats. Diabetes $\mathbf{1 2}$, $115-126(1963)$.

8. Rafaklsen, O.J., V. Lauris, and A.E. Renold: Localized intraperitoneal action of insulin on rat diaphragm and epididymal adipose tissue in vivo. Diabetes 14, 19-26 (1965).

9. Samaan, N., R. Frazer, and W.S. Dempster: The 'typical' and 'atypical' forms of serum insulin. Diabetes 12, 339-348 (1963).

10. YOUNG, D.A.B.: A serum inhibitor of insulin action on muscle: I. Its detection and properties. Diabeto$\operatorname{logia} 3,287-298(1967)$.

Dr. D.A.B. Young, Department of Medicine, Guy's Hospital Medical Sehool, London S. E. 1, England 